\title{
Perifusion of Isolated Rat Adipose Cells
}

\author{
MODULATION OF LIPOLYSIS BY ADENOSINE
}

\author{
B. Paul Turpin, William C. Duckworth, and Solomon S. Solomon
}

From the Departments of Research and Medicine, Veterans Administration Hospital and University of Tennessee Center for the Health Sciences, Memphis, Tennessee 38104

A B S T RA C T Incubation of isolated rat epididymal fat cells is associated with the accumulation of adenosine in the incubation medium. To more clearly define the effect of adenosine on lipolysis, isolated rat epididymal adipocytes were studied with the perifusion system.

Various combinations of epinephrine, adenosine, and adenosine deaminase were perifused through the adipocytes. Exogenous adenosine, 0.001-10.0 $\mu \mathrm{M}$, had no discernible influence upon unstimulated lipolysis; but exogenous adenosine inhibited epinephrine-sensitive lipolysis in a concentration-dependent manner. Cells perifused with $0.3 \mu \mathrm{M}$ epinephrine plus 0.001 $\mu \mathrm{M}$ adenosine did not show any impairment of the lipolytic response to $0.3 \mu \mathrm{M}$ epinephrine alone. Adenosine, $0.01 \mu \mathrm{M}$, inhibited the response to epinephrine by $50 \%$; response to $0.3 \mu \mathrm{M}$ epinephrine plus 0.1 $\mu \mathrm{M}$ adenosine was similar to the basal rate.

Perifusion with adenosine deaminase significantly increased basal lipolysis to $30 \%$ of the epinephrine résponse. Adenosine deaminase and epinephrine were synergistic in stimulating lipolysis to $180 \%$ of the response to epinephrine alone. Isolated fat cells were incubated for $30 \mathrm{~min}$, and the cell-free used medium was perifused through fresh fat cells. Epinephrine in used medium was less effective in promoting lipolysis than epinephrine in fresh buffer. High-pressure liquid chromatography identified adenosine in the used medium. Bovine serum albumin possessed adenosine deaminase activity but accounted for negligible conversion of adenosine to inosine.

Adenosine is shown to have a modulating effect upon

This work was presented, in part, at the Southem Section American Federation for Clinical Research, 1976.

Dr. Turpin is an Associate Investigator of the Veterans Administration. Dr. Duckworth is the recipient of Research Career Development Award AM 00187-01 from the U. S. Public Health Service.

Received for publication 17 February 1977 and in revised form 13 April 1977. basal and hormone-stimulated lipolysis in the perifusion system. Sufficient endogenous adenosine $(<0.01$ $\mu \mathrm{M})$ is present to maximally affect basal lipolysis. Hormone-stimulated lipolysis, although inhibited somewhat by endogenous adenosine, requires the addition of exogenous adenosine for complete inhibition.

\section{INTRODUCTION}

Adenosine has been proposed as a regulatory agent of cyclic AMP metabolism and lipolysis in the adipose cell (1-3). Release of adenosine from the cell (4) and subsequent accumulation of this endogenous nucleoside in the medium of the cell inhibits lipolysis, both basal and catecholamine induced (4). This study was designed to investigate the role of adenosine as a physiological modulator of lipolysis in the isolated fat cell using the newly developed perifusion system $(5,6)$. Both hormone-stimulated and basal lipolysis were examined with this technique.

Previous work in this laboratory (6) has shown that isolated adipose cells will respond to $0.3 \mu \mathrm{M}$ epinephrine delivered through the cell mass at $1 \mathrm{ml} / \mathrm{min}$ $(0.3 \mathrm{nmol} / \mathrm{min})$ with acceleration of lipolysis. A significant increase in glycerol release is seen after exposure to hormone for $5 \mathrm{~min}$ and maximal response to $0.3 \mu \mathrm{M}$ epinephrine is reached within $20 \mathrm{~min}$. Cessation of epinephrine stimulation produces a rapid decline in glycerol output to basal levels well within the 20-min period of buffer wash. Continuation of buffer wash for $75 \mathrm{~min}$ is associated with a constant basal lipolytic rate. Similarly, continued exposure of isolated fat cells to $0.3 \mu \mathrm{M}$ epinephrine is associated with maintenance of maximal lipolysis over $60 \mathrm{~min}$.

In the perifusion system, adenosine inhibited epinephrine-sensitive lipolysis in a concentration-dependent manner. Whereas addition of adenosine to the mileau of the cell produced no apparent change in 
basal lipolysis, removal of adenosine was associated with an increase in lipolysis.

\section{METHODS}

Animals. Male Holtzman rats weighing 150-170 g were used. The animals were fed Purina Laboratory Chow (Ralston Purina Co., St. Louis, Mo.) ad libitum until time of sacrifice by decapitation.

Chemicals. Fatty acid-poor bovine serum albumin, fraction V, lot M45906, was obtained from Armour Pharmaceutical Co., Chicago, Ill. Crude bacterial collagenase, lot 43N111, was purchased from Worthington Biochemical Corp., Freehold, N. J. Adenosine deaminase from calf intestinal mucosa, lot 103C-2490-1; adenosine, inosine, hypoxanthine, adenine, and 1-epinephrine bitartrate were purchased from Sigma Chemical Co., St. Louis, Mo. Adenosine, $\left[8^{-3} \mathrm{H}\right]$ lot 695071 , sp act $16.8 \mathrm{Ci} / \mathrm{mmol}$ was purchased from ICN Pharmaceuticals, Inc., Irvine, Calif. Sodium N-2hydroxyethylpiperazine- $N^{\prime}$-2-ethane sulfonic acid ( $\mathrm{Na}$ Hepes) was purchased from Calbiochem, La Jolla, Calif. All other chemicals were of analytical grade obtained from standard commercial sources.

Preparation of adipose cells. Isolated fat cells were prepared by the methods of Rodbell (7) and Gliemann (8) employing collagenase digestion as modified by Solomon et al. (9). Approximately $1.2 \mathrm{~g}$ of rat epididymal adipose tissue was used for each experiment. After collagenase digestion, cells were washed and then suspended in KrebsRinger bicarbonate buffer containing $1.5 \%$ bovine serum albumin $(\mathrm{BSA})^{1}$ at $\mathrm{pH} 7.4$ and $37^{\circ} \mathrm{C}$. Cells were used either for perifusion or incubation (7).

Perifusion of isolated fat cells. Perifusion of isolated adipocytes employs a modification (6) of the method of Katocs et al. (5). Briefly, $0.4 \mathrm{ml}$ of packed adipose cells are placed in a cylindrical plastic chamber surrounded by a water jacket. Temperature is maintained at $37^{\circ} \mathrm{C}$. Buffer is infused from a nearby reservoir into the packed cell cake through a polyethylene tube which extends into the mass of packed cells. The end of the tube is closed forcing buffer to exit through multiple small holes in the wall of the tube. Cells are gently mixed by the resultant showerhead effect as the buffer passes through the cells. Buffer is delivered through the cell mass at $1.0 \mathrm{ml} / \mathrm{min}$ with constant flow maintained by a polystaltic pump. Cells are initially perifused with buffer alone for $20 \mathrm{~min}$ to allow for attainment of a basal state. Equilibration to a basal state is immediately followed by a 10-min period during which base-line samples of buffer exiting from the perifusion chamber, the perifusate, are collected. During perifusion, samples of perifusate are collected at 2.5-min intervals with an automated fraction collector and immediately placed on ice. Each sample is $2.5 \mathrm{ml}$.

Incubation of isolated adipose cells. Approximately $10^{7}$ isolated adipose cells are suspended in $20 \mathrm{ml}$ buffer in plastic vials and placed in a metabolic shaker for 30-60 min at $37^{\circ} \mathrm{C}$. After incubation the cells are separated from the used medium by centrifugation at $800 \mathrm{rpm}$ for $2 \mathrm{~min}$. This cell-free used medium was used to perifuse fresh cells and assayed for the presence of adenosine.

Measurement of lipolysis. Glycerol content of the perifusate was determined by the fluorometric method of Chernick (10). Glycerol release expressed as nanomoles of glycerol per $10^{5}$ cells per minute is used as an index of lipolytic

${ }^{1}$ Abbreviations used in this paper: ADA, adenosine deaminase; BSA, bovine serum albumin. rate. Because of interexperimental variation in adipose cell responsiveness to hormone stimulation, results of some experiments are expressed on a percentage basis. Lipolytic response to $0.3 \mu \mathrm{M}$ epinephrine is taken as $100 \%$.

Assay of BSA for adenosine deaminase activity. Bovine serum albumin as described above was prepared as a $6 \%$ solution in Krebs-Ringer buffer containing $0.02 \mathrm{M} \mathrm{Na}$ Hepes ( $\mathrm{pH}$ adjusted to 7.4 with $1 \mathrm{~N} \mathrm{HCl}$ before addition of BSA). $2 \mathrm{ml}$ of the $6 \%$ BSA solution containing $\left[8{ }^{3} \mathrm{H}\right]$ adenosine and sufficient unlabeled adenosine to give a final concentration of $37.5 \mathrm{nmol}$ adenosine $/ \mathrm{ml}$ were incubated for $60 \mathrm{~min}$ at $37^{\circ} \mathrm{C}$ in a metabolic shaker. The reaction was terminated with an equal volume of $10 \%$ TCA. After centrifugation the supernatant fluid was washed three times with equal volumes of water-saturated ether. The protein-free fluid was chromatographed on polyethyleneimine-cellulose $F$ thin layer plates (EM Laboratories, Inc., Elmsford, N. Y.) with saturated ammonium sulfate/1 $\mathrm{M}$ sodium acetate/2-propanol (80:18:2) as the developing solvent (11). Development was over 180 min. Unlabeled adenosine, adenine, inosine, and hypoxanthine were also applied. $R_{f}$ values and ultraviolet fluorescence were used to localize migration of the compounds; and associated activity was measured with a liquid scintillation counter (Nuclear Chicago Corp., Des Plaines, Ill.).

Identification of adenosine in incubation medium. After incubation and separation of adipocytes from the used medium, molecular washing was done with an immersible molecular separator (Millipore Corp., Bedford, Mass.). This protein-free filtrate was lyophilized to dryness and dissolved in $1.0 \mathrm{ml}$ water. A $0.5-\mathrm{ml}$ aliquot of this sample was applied to gel filtration with a Sephadex G-10 column (Pharmacia Fine Chemicals, Inc., Piscataway, N. J.). Fractions were collected at 4-min intervals.

Fractions corresponding to the elution time of adenosine were pooled and lyophilized to dryness. The residue was dissolved in water and examined by high pressure liquid chromatography using the cation exchange resin Aminex A-6 (Bio-Rad Laboratories, Richmond, Calif.). Elution was with $0.3 \mathrm{M}$ ammonium formate, $\mathrm{pH}$ 4.5. The eluate was simultaneously monitored for absorbance at 254 and $280 \lambda$.

Conversion of adenosine to inosine with adenosine deaminase. An aliquot of each sample assayed by liquid chromatography was examined for change in optical density at $265 \lambda$ after addition of adenosine deaminase, $0.01 \mu \mathrm{g}$. Measurements were made in quartz cuvettes of $1 \mathrm{~cm}$ path length with a Zeiss PMQ II spectrophotometer (Carl Zeiss, Inc., New York).

Analysis of data. The data was evaluated for significance by Student's $t$ test for nonpaired data.

\section{RESULTS}

Response to varying concentrations of epinephrine. Fig. 1 is the dose-response curve for epinephrinesensitive lipolysis. A submaximal concentration (0.3 $\mu \mathrm{M})$ was chosen as a standard lipolytic stimulus thereby allowing detection of enhanced as well as inhibited lipolysis. Sequential stimulation with maximally effective concentrations of epinephrine is seen in Fig. 2. Perifused isolated fat cells maintain their responsiveness to epinephrine during the experiment. Repeated stimulation does not appear to alter responsiveness.

Response to varying concentrations of adenosine. Fig. 3 represents the effect of adenosine on basal 


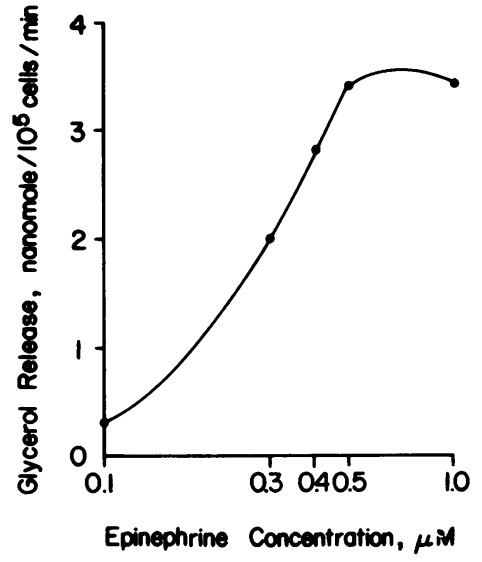

FIGURE 1 Epinephrine dose-response curve in perifused isolated fat cells. Cells are exposed to increasing concentrations of epinephrine ranging from 0.1 to $1.0 \mu \mathrm{M}$. Each concentration is employed for $20 \mathrm{~min}$, followed immediately by the next higher concentration. The peak lipolytic response is obtained at $0.5 \mu \mathrm{M}$ epinephrine. Each point represents the mean of four experiments.

lipolysis. Rates of glycerol release with concentrations of adenosine from 0.001 to $10.0 \mu \mathrm{M}$ were not significantly different from the basal rate of $0.09 \pm 0.01$ (SEM) $\mathrm{nmol}$ glycerol/10 $10^{5}$ cells per min. The effect of adenosine on epinephrine-induced lipolysis is seen in Fig. 4. The lipolytic response to $0.3 \mu \mathrm{M}$ epinephrine, $2.42 \pm 0.44 \mathrm{nmol}$ glycerol $/ 10^{5}$ cells per min, was not significantly affected by $0.001 \mu \mathrm{M}$ adenosine, 2.62 \pm 0.50 . However, $0.01 \mu \mathrm{M}$ adenosine inhibited lipolysis by approximately $50 \%, 1.33 \pm 0.21 \mathrm{nmol}$ glycerol $/ 10^{5}$ cells per $\min (P<0.05)$. Adenosine at 0.1 $\mu \mathrm{M}$ and $1.0 \mu \mathrm{M}$ inhibited completely the response to epinephrine as there was no statistical difference in rates of glycerol release, $0.26 \pm 0.07$ and $0.28 \pm 0.02$, when compared to the basal, $0.22 \pm 0.07 \mathrm{nmol}$ glycerol/ $10^{5}$ cells per min.

Effect of adenosine deaminase. To evaluate the effect of endogenous adenosine on basal lipolysis,

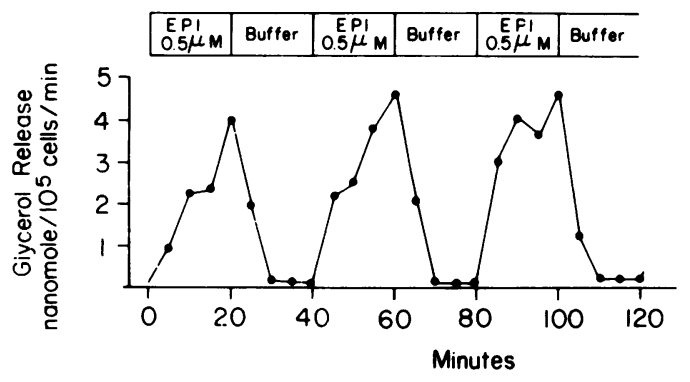

FIGURE 2 One of four experiments showing the lipolytic response to sequential epinephrine (EPI) stimulation. Cells are exposed to maximally effective concentrations of epinephrine for $20 \mathrm{~min}$ followed by buffer wash for $20 \mathrm{~min}$. Cessation of epinephrine is seen to cause a rapid decline in lipolysis to the basal level.

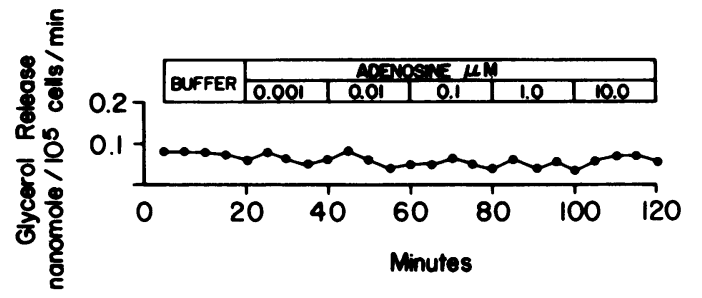

FIGURE 3 A representative experiment, one of four, showing the effect on basal lipolysis of varying concentrations of adenosine. After perifusion with buffer alone, cells are exposed sequentially to increasing concentrations of adenosine ranging from 0.001 to $10 \mu \mathrm{M}$.

cells were perifused with buffer containing $1 \mu \mathrm{g} / \mathrm{ml}$ adenosine deaminase (ADA). In the presence of ADA perifused isolated adipocytes increase lipolysis significantly above basal activity, $0.22 \pm 0.07$ vs. $0.75 \pm 0.10$ nmol glycerol $/ 10^{5}$ cells per $\min (P<0.05)$. Fig. 5 shows glycerol release in response to ADA is $30 \%$ of the response with $0.3 \mu \mathrm{M}$ epinephrine. Perifusion with $0.3 \mu \mathrm{M}$ epinephrine and $1 \mu \mathrm{g} / \mathrm{ml}$ ADA produced lipolysis similar in magnitude to that seen with epinephrine, ADA, and $0.1 \mu \mathrm{M}$ adenosine. The inhibitory effect of $0.1 \mu \mathrm{M}$ adenosine on epinephrinestimulated lipolysis is removed by addition of ADA, $0.26 \pm 0.07$ vs. $4.37 \pm 0.43 \mathrm{nmol}$ glycerol $/ 10^{5}$ cells per min (Table I).

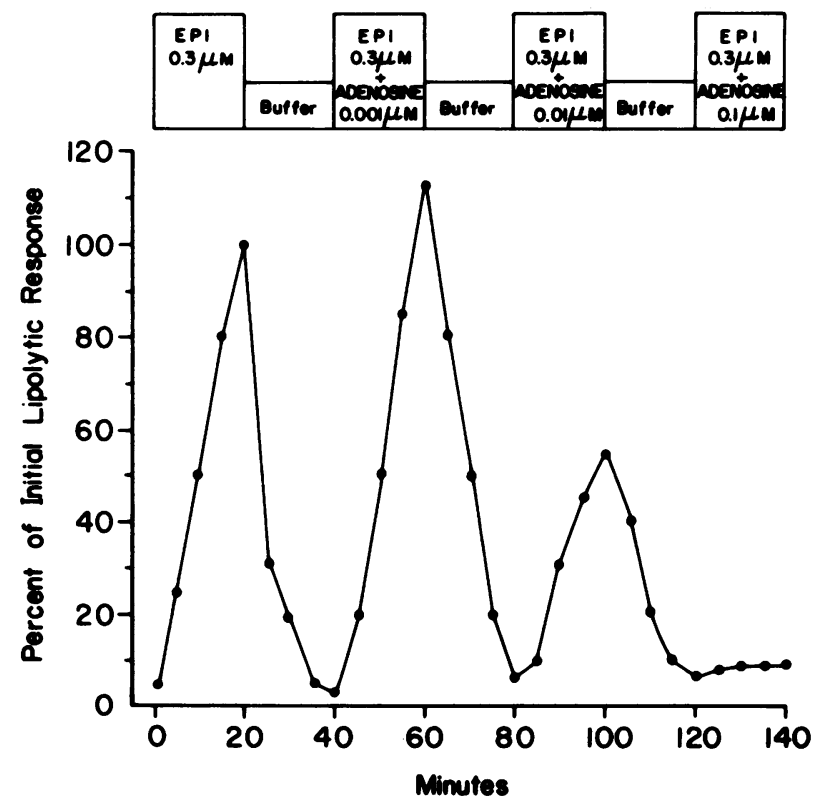

FIGURE 4 A representative experiment of four showing the effect of adenosine on epinephrine-induced lipolysis in perifused isolated fat cells. Cells are initially stimulated with $0.3 \mu \mathrm{M}$ epinephrine (EPI). Responses are plotted as percentage of initial lipolytic response $(2.42 \pm 0.44 \mathrm{nmol}$ glycerol $/ 10^{5}$ cells per min). After a buffer wash, cells are stimulated with $0.3 \mu \mathrm{M}$ epinephrine plus adenosine in concentrations $0.001,0.01$, and $0.1 \mu \mathrm{M}$. 


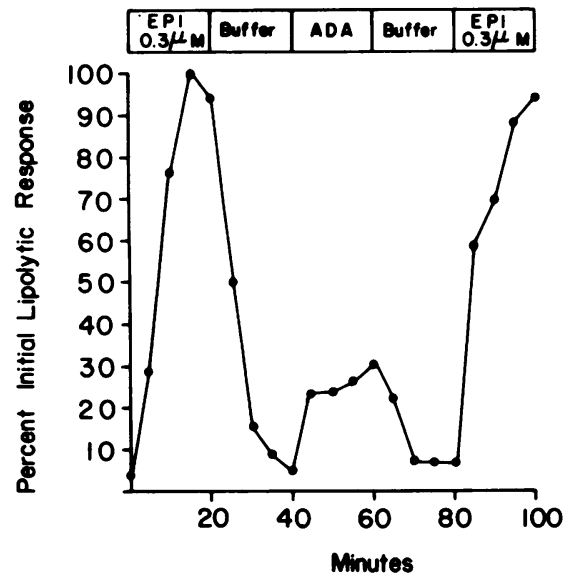

Figure 5 A representative of three experiments showing the effect of adenosine deaminse (ADA) on perifused isolated fat cells. Cells are stimulated initially with $0.3 \mu \mathrm{M}$ epinephrine (EPI). Following a buffer wash, cells are exposed to $1 \mu \mathrm{g} / \mathrm{ml}$ ADA and finally to $0.3 \mu \mathrm{M}$ epinephrine. Response is plotted as percentage of initial lipolytic response to $0.3 \mu \mathrm{M}$ epinephrine $\left(2.52 \pm 0.17 \mathrm{nmol}\right.$ glycerol $/ 10^{5}$ cells per $\min$ ).

Effect of used incubation medium. Perifusion with used incubation medium is represented in Fig. 6 . Epinephrine is seen to be less effective as a lipolytic hormone in used medium when compared to its effect in fresh buffer, $3.21 \pm 0.36$ vs. $2.25 \pm 0.41 \mathrm{nmol}$ glycerol $/ 10^{5}$ cells per min $(P<0.05)$. Addition of $1 \mu \mathrm{g} / \mathrm{ml}$ ADA to used medium containing $0.3 \mu \mathrm{M}$ epinephrine removed the inhibitory factor and enhanced lipolysis

TABLE I

Effect of Adenosine Deaminase on Lipolysis in Perifused Isolated Fat Cells

\begin{tabular}{|c|c|c|c|}
\hline Additions & $\begin{array}{l}\text { Epinephrine } \\
\text { response }\end{array}$ & No. & $P$ value \\
\hline & $\%$ & & \\
\hline None & 10 & $n=4$ & $<0.05^{*}$ \\
\hline $\begin{array}{l}\text { Adenosine deaminase, } \\
\quad 1 \mu \mathrm{g} / \mathrm{ml}\end{array}$ & 30 & $n=3$ & $<0.05 \ddagger$ \\
\hline Epinephrine, $0.3 \mu \mathrm{M}$ & 100 & $n=4$ & - \\
\hline $\begin{array}{l}\text { Epinephrine, } 0.3 \mu \mathrm{M} \\
\quad+\text { Adenosine, } 0.1 \mu \mathrm{M}\end{array}$ & 10 & $n=4$ & $<0.05^{*}$ \\
\hline $\begin{array}{l}\text { Epinephrine, } 0.3 \mu \mathrm{M} \\
\quad+\text { Adenosine deaminase, } \\
1 \mu \mathrm{g} / \mathrm{ml} \\
\text { Epinephrine, } 0.3 \mu \mathrm{M} \\
\quad+\text { Adenosine, } 0.1 \mu \mathrm{M} \\
+ \text { Adenosine deaminase, } \\
1 \mu \mathrm{g} / \mathrm{ml}\end{array}$ & 180 & $n=4$ & $<0.05^{*}$ \\
\hline
\end{tabular}

* Versus lipolytic response with $0.3 \mu \mathrm{M}$ epinephrine.

‡ Versus basal lipolytic rate.

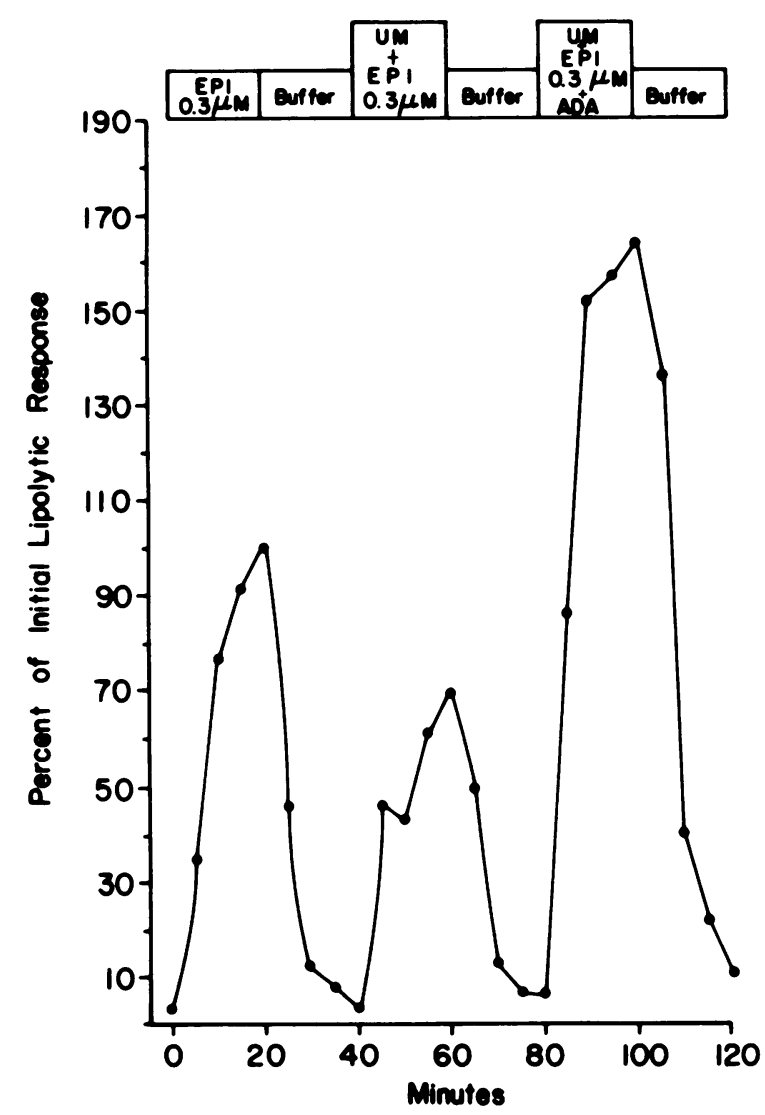

FIGURE 6 A representative of four experiments showing the response to epinephrine (EPI) in fresh and used medium. Cells are initially exposed to $0.3 \mu \mathrm{M}$ epinephrine in fresh buffer. After a buffer wash, cells are exposed to $0.3 \mu \mathrm{M}$ epinephrine in medium which has been used for incubation of isolated fat cells (UM). Again after buffer wash, cells are exposed to $0.3 \mu \mathrm{M}$ epinephrine in $\mathrm{UM}$ to which $1 \mu \mathrm{g} / \mathrm{ml}$ ADA has been added. Responses are recorded as percent of the initial response to epinephrine $(3.21 \pm 0.36 \mathrm{nmol}$ glycerol $/ 10^{5}$ cells per $\mathrm{min}$ ).

when compared to epinephrine in fresh buffer, 5.31 \pm 0.38 vs. $3.21 \pm 0.36 \mathrm{nmol}$ glycerol $/ 10^{5}$ cells per min $(P<0.05)$. This is compatible with results obtained with epinephrine and ADA in fresh buffer (Table I).

Identification of adenosine in incubation medium. A fraction obtained from used medium as described in Methods is seen to co-chromatograph with a standard solution of adenosine (Fig. 7). Panel A represents $50 \mu \mathrm{g}$ adenosine and panel $\mathrm{B}$ represents the used medium fraction. Standard solutions of adenine and inosine were also chromatographed. Each compound exhibited a specific elution time and a characteristic $254 \lambda / 280 \lambda$ absorbance ratio. Only adenosine was identified in the used medium. Fig. 8 represents the change in optical density of used medium (prepared as described in Methods) after addition of $0.01 \mu \mathrm{g}$ ADA. With a standard adenosine concentration of 0.1 

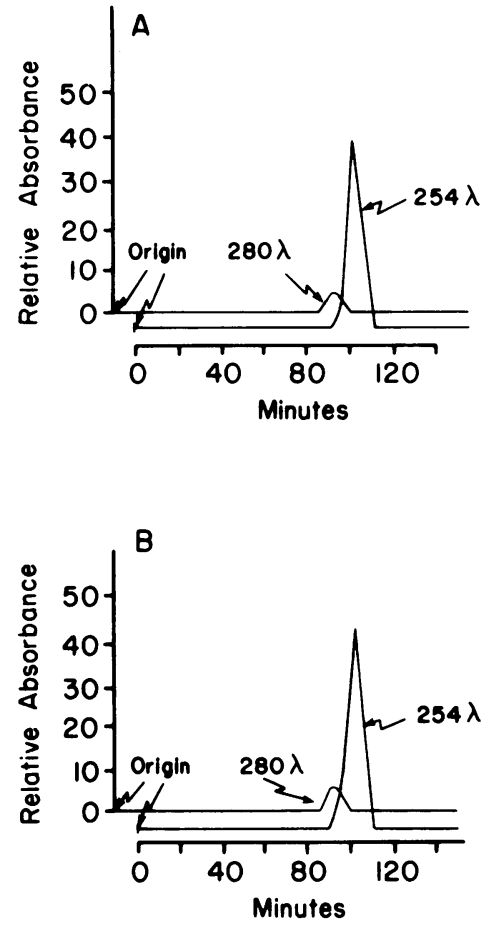

FIGURE 7 A. Chromatography obtained with $50 \mu$ g adenosine applied to cation exchange resin with high pressure liquid chromatography. B. Chromatograph obtained with fluid prepared from medium in which isolated fat cells were incubated. The similarity in the shape of the peaks is the result of differences in the sensitivity of the UV monitor. The concentration of adenosine in panel B is much less than $50 \mu \mathrm{g}$.

$\mu \mathrm{M}$, the change in optical density was 0.6 and with used medium 0.5 after 5 min.

Assay of BSA for ADA activity. Reports of ADA activity in BSA (12) prompted an examination of the albumin used in these studies. Endogenous ADA activity associated with albumin was identified as a component of the medium used in all experiments.

However, even at a concentration of $6 \%$ the albumin used in these studies deaminated 16.6 pmol adenosine/h. Such activity would not have contributed a measurable effect to the results of these experiments.

\section{DISCUSSION}

Lipolysis in the incubated fat cell has been shown to be altered by the accumulation in the incubation media of materials released from the fat cells $(4,13,14)$. One of the most important of these substances is adenosine (4), and variations in lipolytic rate seen in certain situations have been attributed to changes in adenosine concentration (4). One example of this is the lower rate of basal lipolysis in incubations containing a high concentration of fat cells, due to the antilipolytic effect of adenosine released by the large number of cells (4). Some of the variations in the suitability of different lots of albumin for use in the study of isolated fat cells may be due to differences in the degree of contamination with ADA (12). The ADA in turn would affect the responsiveness of the cells by changing the adenosine concentration in the media. It should be noted that the albumin used in the present study contained negligible ADA activity.

Studies on the effect of adenosine on lipolysis have been done with the incubated fat cell in which adenosine and other materials accumulate during the experiment. For this reason we have chosen to study the effect of adenosine on lipolysis in the perifused isolated fat cell in which system accumulation of products would be expected to be minimal. This system responds promptly to epinephrine stimulation by increasing lipolysis and also responds promptly to the removal of epinephrine by restoration of the basal rate of lipolysis. Repeated stimulatory doses of epinephrine elicit similar lipolytic response (6).

In this perifusion system exogenous adenosine had no effect on the basal lipolytic rate. In spite of the lack of effect of exogenous adenosine, the addition of ADA significantly stimulated basal lipolysis as has been seen in previous studies of incubated fat cells (15). ADA converts adenosine to inosine rapidly and irreversibly (16). Inosine has no significant effect on the fat cell except in very high concentrations (16) much higher than would be expected to be seen in the perifusion system. Similarly, ammonia is not known to affect lipolysis at concentrations present in these experiments (17). In an extensive series of experiments Fain and Wieser examined the effects of ADA on the fat cell and concluded that all the effects were

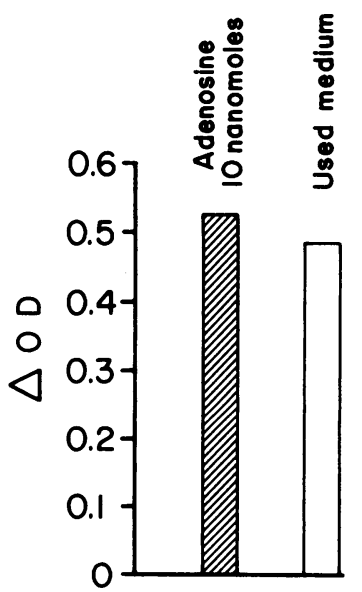

FIGURE 8 Change in the optical density (OD) at 265 $\lambda$ after addition of $0.01 \mu \mathrm{g}$ ADA. The hatched bar represents 10 nmoles adenosine and the clear bar represents proteinfree concentrated material released from isolated fat cells during incubation. The change in $O D$ is the total change after 5 min. 
due to the removal of extracellular adenosine (15). This suggests that even in the perifused fat cell endogenous adenosine release is enough to alter significantly basal lipolysis. In fact, the lack of further suppression by exogeneous adenosine suggests that maximal suppression of basal lipolysis is accomplished by endogenous adenosine $(<0.01 \mu \mathrm{M})$.

Further evidence supporting the presence of endogenous adenosine in the perifusion system is the potentiation of epinephrine-induced lipolysis by ADA. These results suggest adenosine present in the media or associated with the external surface of the plasma membrane and thus susceptible to ADA, was partially inhibiting the response to epinephrine. This effect is similar to the inhibition of basal lipolysis. In contrast to basal lipolysis, however, exogenous adenosine had a potent effect on epinephrine-stimulated lipolysis. Adenosine at $0.01 \mu \mathrm{M}$ suppressed the response to a submaximal dose of epinephrine $(0.3 \mu \mathrm{M})$ by $50 \%$ and $0.1 \mu \mathrm{M}$ or greater adenosine totally inhibited epinephrine-induced lipolysis. The addition of ADA in this situation, i.e., exogenous adenosine and epinephrine, resulted in lipolysis greater than epinephrine alone and similar to epinephrine and ADA together. Similar results have been reported from incubation studies $(15,16)$ in which ADA potentiated response to submaximal concentrations of epinephrine; however, ADA alone was equipotent when compared to maximal stimulation with epinephrine.

To study further the effect of material released from adipose cells, media in which cells had incubated was perifused through fresh cells. This media had no effect on basal lipolysis but partially inhibited the lipolytic response to epinephrine. ADA reversed this inhibition and produced a final lipolytic rate comparable to that seen with ADA and epinephrine in fresh buffer either with or without exogenous adenosine. This strongly supports the idea that the inhibition seen with the used media was due to the presence of adenosine. This was confirmed by isolating adenosine from the used media.

Accumulation of free fatty acids in the environment of rat adipose cells has been shown to inhibit lipolysis $(12,13,18)$. However, free fatty acids probably do not accumulate in the perifusion system in sufficient concentration to exceed the capacity of albumin to bind them. Further, the removal by ADA of the inhibitory potential of used medium does not favor a major role for free fatty acids in these studies.

The role of adenosine as a modulator of lipolysis in the physiologic situation is supported by the results of these perifusion experiments. Under conditions of nonaccumulation of metabolic by-products, various manipulations of adenosine concentration produced discernible changes in the metabolism of the fat cell. This was particularly evident when endogenous aden- osine was removed by enzymatic activity. More evidence in support of adenosine as a physiologic effector of lipolysis is reported by Fredholm (19) in studies of perfused canine subcutaneous adipose tissue. By prelabeling the tissue with $\left[{ }^{3} \mathrm{H}\right]$ adenine, he demonstrated alterations in the rate of glycerol release associated with changes in labeled nucleoside release. Although other factors, such as altered blood flow, contributed to the total effect seen in his work, the change in tissue nucleoside levels supports the premise that adenosine is a physiologically important modifier of lipolysis. Another series of studies on lipolysis in acidosis, in which lipolysis is reduced, did not show clear cut alterations in adenosine levels although it was felt that some of the decrease in lipolysis could have been due to adenosine (20). Other conditions need to be examined, particularly hypoxia, which has been associated with adenosine release in other tissues. It may well turn out that adenosine is a local regulatory agent in adipose tissue as it is in muscle (21) and brain (22).

\section{ACKNOWLEDGMENTS}

The authors wish to thank Dr. John N. Fain for advice and manuscript critique, Dr. Tom Huber for manuscript critique, and Dr. Ray Cox and Ms. Susan Mathes for advice and technical assistance, respectively.

This study was conducted under Veterans Administration Research Project S 8036-01 and -04, 1942-04, and 8569-01 and was supported, in part, by National Institutes of Health grant AM 18022.

\section{REFERENCES}

1. Fain, J. N. 1973. Inhibition of adenosine cyclic $3^{\prime}, 5^{\prime}-$ monophosphate accumulation in fat cells by adenosine, $\mathrm{N}^{6}$-(phenylisopropyl) adenosine, and related compounds. Mol. Pharmacol. 9: 595-604.

2. Ebert, R., and U. Schwabe. 1973. Studies on the antilipolytic effect of adenosine and related compounds in isolated fat cells. Naunyn-Schmiedbergs Arch. Pharmakol. 278: 247-259.

3. Fain, J. N., R. H. Pointer, and W. F. Ward. 1972. Effects of adenosine nucleosides on adenylate cyclase, phosphodiesterase, cyclic adenosine monophosphate accumulation, and lipolysis in fat cells. J. Biol. Chem. 247: 6866-6872.

4. Schwabe, U., R. Ebert, and H. C. Erbler. 1973. Adenosine release from isolated fat cells and its significance for the effects of hormones on cyclic $3^{\prime}, 5^{\prime}$-AMP levels and lipolysis. Naunyn-Schmiedbergs Arch. Pharmakol. 276: 133-148.

5. Katocs, A. S., Jr., E. E. Largis, D. O. Allen, and J. Ashmore. 1973. Perifused fat cells: Effects of lipolytic agents. J. Biol. Chem. 248: 5089-5094.

6. Solomon, S. S., and W. C. Duckworth. 1976. Effect of antecedent hormone administration on lipolysis in the perifused isolated fat cell.J. Lab. Clin. Med. 88: 984-994.

7. Rodbell, M. 1964. Metabolism of isolated fat cells: I. Effects of hormones on glucose metabolism and lipolysis. J. Biol. Chem. 239: 375-380.

8. Gliemann, J. 1965. Insulin-like activity of dilute human 
serum assayed by isolated adipose tissue cell method. Diabetes. 14: 643-649.

9. Solomon, S. S., L. E. King, Jr., and K. Hashimoto. 1975. Studies of the biological activity of insulin, cyclic nucleotides, and concanavalin $A$ in the isolated fat cell. Horm. Metab. Res. 7: 297-304.

10. Chernick, S. S. 1969. Determination of glycerol in acyl glycerol. Methods Enzymol. 14: 627-630.

11. Parker, J. C., C. E. Jones, and E. E. Smith. 1973. Determination of acid-soluble nucleosides and bases in myocardium by thin-layer methods. J. Chromatogr. 79: 360-363.

12. Fain, J. N., and R. E. Shepherd. 1976. Hormonal regulation of lipolysis: Role of cyclic nucleotides, adenosine and free fatty acids. In Proceedings of the 12th Midwest Conference on Endocrinology and Metabolism. Plenum Publishing Corp., New York.

13. Fain, J. N., and R. E. Shepherd. 1976. Inhibition of adenosine $3^{\prime}: 5^{\prime}$-monophosphate accumulation in white fat cells by short chain fatty acids, lactate, and $\beta$-hydroxybutyrate. J. Lipid Res. 17: 377-385.

14. Ho, R-J., and E. W. Sutherland. 1975. cAMP-mediated feedback regulation in target cells. Adv. Cyclic Nucleotide Res. 5: 533-548.

15. Fain, J. N., and P. B. Wieser. 1975. Effect of adenosine deaminase on cyclic adenosine monophosphate accumulation, lipolysis, and glucose metabolism of fat cells. J. Biol. Chem. 250: 1027-1034.
16. Schwabe, U., and R. Ebert. 1974. Stimulation of cyclic adenosine $3^{\prime}, 5^{\prime}$-monophosphate accumulation and lipolysis in fat cells by adenosine deaminase. NaunynSchmiedbergs Arch. Pharmakol. 282: 33-44.

17. Mosinger, B., and M. Vaughan. 1967. Effects of electrolytes on epinephrine-stimulated lipolysis in adipose tissue in vitro. Biochim. Biophys. Acta. 144: 556-568.

18. Fain, J. N., and R. E. Shepherd. 1975. Free fatty acids as feedback regulators of adenylate cyclase and cyclic $3^{\prime}, 5^{\prime}$-AMP accumulation in rat fat cells. J. Biol. Chem. 250: 6586-6592

19. Fredholm, B. B. 1976. Release of adenosine-like material from isolated perfused dog adipose tissue following sympathetic nerve stimulation and its inhibition by adrenergic $\alpha$ receptor blockade. Acta Physiol. Scand. 96: $422-430$.

20. Hjemdahl, P., and B. B. Fredholm. 1976. Cyclic AMPdependent and independent inhibition of lipolysis by adenosine and decreased pH. Acta Physiol. Scand. 96: $170-179$.

21. Wiessel, M., G. Raberger, and O. Kraupp. 1973. The effects of intra-arterial adenosine infusion on substrate levels and blood flow in skeletal muscle of the dog. Naunyn-Schmiedbergs Arch. Pharmakol. 277: 239-252.

22. Rubio, R., R. M. Berne, E. L. Bockman, and R. R. Curnish. 1975. Relationship between adenosine concentration and oxygen supply in rat brain. Am. J. Physiol. 222: $1896-1902$. 